\title{
Dapatkah Pembayaran Jasa Lingkungan Mencegah Deforestasi dan Meningkatkan Kesejahteraan Masyarakat?: Pelajaran dari Hutan Desa Laman Satong, Kabupaten Ketapang, Kalimantan Barat
}

\section{Can Payment for Environment Services avoid Deforestation and Increase Wellbeing?: a Lesson Learned from Laman Satong Village Forest, Ketapang District, West Kalimantan Province}

\author{
Cahyo Nugroho $^{\mathrm{a}}$, Jatna Supriatna ${ }^{\mathrm{b}}$, Ahmad Kusworo ${ }^{\mathrm{c}}$ \\ ${ }^{\text {a }}$ Program Studi Ilmu Lingkungan Sekolah Ilmu Lingkungan, Universitas Indonesia, Telp. +6281380014700 \\ ${ }^{\mathrm{b}}$ Program Studi Ilmu Lingkungan Sekolah Ilmu Lingkungan Universitas Indonesia; Departemen Biologi FMIPA Universitas \\ Indonesia; Research Center for Climate Change (RCCC) Universitas Indonesia \\ ${ }^{\mathrm{c}}$ Fauna \& Flora International Indonesia Programme, Jakarta
}

\section{Article Info:}

Received: 09 - 05 - 2018

Accepted: 06 - 05 - 2019

Keywords:

Payment for environment services, REDD+, village forest, deforestation, wellbeing.

Corresponding Author:

Cahyo Nugroho

Program Studi Ilmu Lingkungan

Sekolah Ilmu Lingkungan,

Universitas Indonesia;

Tel. +6281380014700

Email:

nugroho.cahyo@gmail.com

\begin{abstract}
In order to reduce deforestation, the Government of Indonesia has introduced several initiativies, including a Hutan Desa (village forest) program to bring local communities to become actor in the forest management. The Reduced Emissions from Deforestation and Forest Degradation plus (REDD+) and Payment for Environmental Services (PES) scheme for the hutan desa is one of the alternative scheme to provide economic incentives for their effort to manage their forest sustainably. This study aims to evaluate the impact of the initiation of REDD+ and PES funds for hutan desa to deforestation and community wellbeing. The impact to deforestation is measured through quantitative approach by comparing quantitatively forest cover on 1070ha of village forest through satelite image analysis. The impact to community wellbeing is measured through participatory wellbeing assessment involving 30 informants during a focus group discussion. An attribution to the variables are conducted qualitatively by in-depth interviews to 25 key informants. The result shows eventhough the benefit provided by the initiation of REDD+ and PES (the money) is much less than the opportunity cost, the community is still accepting the scheme and succeeds reducing deforestation. However, the benefit is not sufficient enough yet to improve community wellbeing.
\end{abstract}

How to cite (CSE Style $8^{\text {th }}$ Edition):

Nugroho C, Supriatna J, Kusworo A. 2019. dapatkah pembayaran jasa lingkungan mencegah deforestasi dan meningkatkan kesejahteraan masyarakat?: pelajaran dari hutan desa laman satong, kabupaten ketapang, kalimantan barat. JPSL 9(4): 882-892. http://dx.doi.org/10.29244/jps1.9.4.882-892.

\section{PENDAHULUAN}

Ketidakberlanjutan pengelolaan sektor kehutanan tidak hanya diindikasikan oleh deforestasi namun juga disebabkan fakta bahwa masyarakat di dalam dan sekitar kawasan hutan masih miskin atau keadaan ekonomi yang memprihatinkan (Rositah 2006; Departemen Kehutanan dan Badan Pusat Statistik 2007). Masyarakat selama ini seperti dilupakan, padahal mereka adalah aktor yang sangat penting dalam pengelolaan hutan yang berkelanjutan. Program hutan desa memberikan kesempatan masyarakat melalui hak kelola untuk mengelola hutan mereka, sekaligus membuktikan bahwa mereka mampu menjaga hutan secara berkelanjutan (Peraturan Menteri Kehutanan P. 89/2014 tentang Hutan Desa). Skema Reduced Emission from Deforestation and Forest 
Degradation plus (REDD+) dan Pembayaran Jasa Lingkungan (PJL) untuk hutan desa adalah salah satu alternatif usaha untuk memberikan insentif secara ekonomi terhadap program hutan desa. Salah satu desa yang telah mendapatkan manfaat skema tersebut adalah Desa Laman Satong, Kabupaten Ketapang, Kalimantan Barat.

Skema pembayaran jasa lingkungan (PJL) untuk REDD+ dinilai sebagai instrumen yang efektif dengan biaya yang efisien (Wunder 2009; Yayasan Resource Development Center 2009; Bond et al. 2009). Skema PJL dapat didefinisikan sebagai sebuah sistem yang transparan untuk penyediaan jasa lingkungan melalui pembayaran bersyarat pada penyedia jasa secara sukarela (Tacconi 2012). Skema PJL sebagai produk hukum lingkungan mengacu pada UU 32 tahun 2009 tentang Perlindungan dan Pengelolaan Lingkungan Hidup. Skema tersebut adalah instrumen ekonomi dalam pengelolaan dan perlindungan lingkungan hidup di Indonesia (pasal 43 ayat 3 ).

Beberapa studi menunjukkan bahwa insentif ekonomi melalui skema PJL dapat memberikan dampak ekonomi, sosial, dan lingkungan yang berbeda derajatnya di beberapa tapak yang diteliti (Bond et al. 2009; Wunder 2009; Tacconi et al. 2013; Kaczan et al. 2013; Lapeyrea et al. 2015). Bond et al. (2009) dan Wunder (2009) menilai bahwa skema PJL untuk REDD+ memiliki peran yang penting untuk mengurangi alih fungsi dan kerusakan hutan.

Studi lain menunjukkan bahwa skema PJL dengan derajat yang berbeda-beda di beberapa kasus berdampak terhadap (i) modal fisik dan finansial, (ii) modal manusia (human capital), (iii) modal sosial, dan (iv) modal alam (Leimona dan Joshi 2009; Tacconi et al. 2013). Dampak yang dimaksud dapat berupa dampak positif maupun dampak negatif. Dampak negatif yang muncul adalah rasa ketidakadilan dalam membagi manfaat PJL (Tacconi et al. 2013). Kegagalan dalam membagi manfaat merupakan ancaman keberlanjutan skema ini (Torpey-Saboe et al. 2015). Skema PJL di beberapa tapak menunjukkan bahwa skema ini mampu meningkatkan kesejahteraan masyarakat secara tidak langsung melalui kegiatan pemberdayaan masyarakat (Leimona dan Joshi 2009).

Perumusan masalah untuk riset ini adalah inisiasi skema REDD+ dan PJL untuk hutan desa telah diterapkan di Desa Laman Satong, namun dampak inisiasi skema tersebut terhadap deforestasi dan kesejahteraan masyarakat belum dievaluasi. Berdasarkan rumusan masalah tersebut, pertanyaan riset adalah: (i) bagaimana inisiasi skema REDD+ dan PJL berdampak terhadap deforestasi yang diukur dari tutupan hutan,

(ii) bagaimana inisiasi skema REDD+ dan PJL berdampak terhadap kesejahteraan masyarakat.

\section{METODE}

\section{Lokasi dan Waktu Penelitian}

Riset dilakukan di Dusun Manjau Desa Laman Satong Kecamatan Matan Hilir Utara Kabupaten Ketapang Propinsi Kalimantan Barat. Lokasi riset dipilih karena merupakan lokasi hutan desa pertama di Indonesia yang mendapatkan insentif dari inisiasi skema REDD+ dan PJL.

Hutan Desa Laman Satong seluas 1,070 ha terletak di sebelah selatan dari Taman Nasional Gunung Palung dan Gunung Tarak dan sebelah utara dari perkebunan kelapa sawit dan konsesi tambang bauksit. Hutan Desa ini terletak di $101.9^{\circ}-101.8^{\circ}$ bujur timur dan di $2.2^{\circ}-2.3^{\circ}$ lintang selatan, dengan ketinggian berada dari 1-400 m di atas permukaan laut. Hampir sebagian besar area terletak di kelerengan landai antara 0.5-30\%, sebagian kecil berada di kelerengan curam 40-53\% (FFI 2012).

Di dalam area ini terdapat beberapa anak sungai. Sebagian anak sungai tersebut mengalir ke arah utara menuju Sungai Siduk, sebagian lainnya mengarah ke arah selatan menuju Sungai Kuala Satong. Sungai Siduk dan Sungai Kuala Satong merupakan bagian dari daerah aliran Sungai Pawan. Di dalam hutan terdapat mata air sebagai sumber utama air bersih bagi masyarakat.

Waktu riset dilakukan selama beberapa tahap. Tahap pertama di lakukan di bulan April 2015 untuk mendapatkan data terkait dengan deforestasi dan degradasi hutan. Pengambilan data melalui Focus Group Discussion (FGD) baru dapat dilakukan pada bulan Oktober 2015 disebabkan oleh asap di sekitar lokasi, 
kebakaran besar hutan Kalimantan. Tahap terakhir dilakukan di bulan Maret 2016 untuk memverifikasi data yang telah diperoleh pada pengambilan data sebelumnya sekaligus memberikan atribusi terhadap variabel yang diteliti.

\section{Deskripsi Masyarakat Desa Laman Satong}

Afiff et al. (2011) mengidentifikasi Masyarakat Desa Laman Satong sebagian besar beretnis Dayak, sebagian kecil lainnya berasal dari Etnis Melayu, Jawa, dan Cina. Sebagian besar masyarakat memeluk agama Kristen Katolik, sebagian lainnya merupakan pemeluk agama Kristen Protestan, Islam dan Budha. Para warga yang beretnis Dayak dan Cina identik dengan Agama Kristen Katolik, Protestan dan Budha, sedangkan Etnis Melayu dan Jawa identik dengan Agama Islam.

Komposisi penduduk berdasarkan gender hampir seimbang yaitu penduduk laki-laki berjumlah 1,405 dan perempuan sebanyak 1,278 jiwa (BPS Kabupaten Ketapang 2014). Ada pun rata-rata warga memiliki latar belakang pendidikan terakhir Sekolah Dasar dan SMP. Relatif rendahnya latar belakang pendidikan warga Desa Laman Satong disebabkan karena terlambatnya pembangunan gedung sekolah tingkat lanjutan di desa ini (Afiff et al. 2010).

Mata pencaharian utama masyarakat adalah peladang. Hadirnya perusahaan tambang batu dan perusahaan kelapa sawit mengakibatkan terjadi perubahan dalam sistem mata pencaharian mereka. Pandangan tentang jenis pekerjaan yang dapat memberikan penghasilan dalam tempo singkat, seperti menjadi buruh upah harian di perkebunan kelapa sawit atau perusahaan tambang batu menggeser etos kerja berladang yang merupakan sumber mata pencaharian yang membutuhkan waktu yang relatif lama untuk dapat menikmati hasilnya (Afiff et al. 2010).

\section{Deskripsi Skema REDD+ dan PJL}

Inisiasi skema REDD+ dan PJL untuk hutan desa adalah inisiasi skema pembayaran kepada masyarakat atas kinerja mereka mencegah deforestasi dan degradasi hutan untuk menjaga jasa lingkungan berupa cadangan karbon di area hutan desa mereka. Pembayaran kepada masyarakat dirancang berdasarkan kinerja masyarakat dalam menjaga tutupan hutan. Jika masyarakat mampu menjaga tutupan hutan sesuai dengan kesepakatan yang dibuat bersama antara pembeli jasa lingkungan dan penyedia jasa lingkungan (masyarakat), maka pihak fasilitator membayarkan sejumlah uang untuk masyarakat. Pembeli yang dimaksud dalam inisiasi skema ini adalah donor pemberi bantuan (grant) yang menyetujui pembayaran kepada masyarakat melalui lembaga pendamping.

Nilai kontrak yang dibuat antara masyarakat dan pembeli tergantung kepada besarnya ketersediaan dana dari donor/pembeli. Ketersediaan dana tersebut digunakan untuk membeli sertifikat karbon yang tersedia berdasarkan standar plan vivo (planvivo.org). Karbon yang berhasil disertifikasi sesuai standar plan vivo untuk hutan desa ini adalah 4,258 $\mathrm{tCO}_{2} \mathrm{e}$ (FFI, 2012). Di tahun pertama, dana yang tersedia hanya mampu membeli $710 \mathrm{tCO}_{2} \mathrm{e}$ dari total 4,258 ton atau setara dengan $16.6 \%$ dari total $\mathrm{tCO}_{2} \mathrm{e}$ tersedia. Di tahun kedua terjual 1,065 $\mathrm{tCO}_{2} \mathrm{e}$ atau setara dengan $25 \%$ dari total $\mathrm{tCO}_{2} \mathrm{e}$. Artinya $75 \%$ dari ton $\mathrm{CO}_{2} \mathrm{e}$ yang tersedia belum dapat terjual.

Periode pertama implementasi inisiasi skema REDD+ dan PJL untuk hutan desa di Desa Laman Satong dimulai di bulan Mei 2013 sampai dengan April 2014 (selanjutnya disebut periode 2013/2014). Periode tersebut disebut sebagai periode persiapan pembayaran. Semua aktivitas pengeloaan hutan dan pelatihan sepenuhnya dibiayai oleh lembaga pendamping. Nilai kontrak yang disepakati adalah Rp. 100 juta apabila di akhir periode masyarakat berhasil menjaga hutannya. Dalam periode pertama ini, masyarakat diberikan insentif dibayarkan 100\%. Pembayaran dibagi dalam 2 tahap yaitu di Rp. 50 juta di bulan April 2014 dan Rp. 50 juta di bulan November 2014. Periode kedua dilaksanakan dari bulan April 2014 sampai dengan Maret 2015 (selanjutnya disebut sebagai periode 2014/2015) dengan nilai kontrak Rp. 150 juta. 


\section{Metode Pengumpulan Data}

Metode pengumpulan data dilakukan secara komparatif membandingkan data tutupan hutan dan hasil participatory wellbeing asessment (PWA) sebelum dan selama skema (intervensi) berjalan. Data tutupan hutan meliputi: (i) data titik dan poligon hutan yang terbuka, (ii) citra satelit secara historis dari tahun 2013 dan 2014, (iii) data verifikasi ground check. Data kesejahteraan masyarakat meliputi: (i) data jumlah rumah/keluarga yang berada di kelompok miskin, sedang, atau kaya, yang diperoleh melalui Participatory Wellbeing Assesment (PWA). Data PWA diperoleh dari data PWA tahun 2013 dan PWA tahun 2015 yang dilakukan melalui Focus Group Discussion (FGD).

\section{Metode Analisis Data}

Riset dilakukan dengan pendekatan kuantitatif yaitu membandingkan secara kuantitatif tutupan hutan seluas 1070 ha sebelum dan selama skema berjalan. Tutupan hutan dibagi berdasarkan SNI 7645-2010 (BSN 2010) tentang klasifikasi penutupan lahan dengan penyesuaian, yaitu:

a) Hutan Campuran Rapat (HCR): Hutan yang tumbuh berkembang pada habitat lahan kering yang telah mengalami intervensi manusia dengan kerapatan $>70 \%$.

b) Hutan Campuran Sedang (HCS): Hutan yang tumbuh berkembang pada habitat lahan kering yang telah mengalami intervensi manusia dengan kerapatan $41 \%-70 \%$.

c) Hutan Campuran Jarang (HCJ): Hutan yang tumbuh berkembang pada habitat lahan kering yang telah mengalami intervensi manusia dengan kerapatan kurang dari $41 \%$ sampai $10 \%$

d) Semak Belukar (SB): Kawasan lahan kering yang telah ditumbuhi berbagai vegetasi alami heterogen dan homogen yang tingkat kerapatannya jarang hingga rapat. Kawasan tersebut didominasi vegetasi rendah (alami). Biasanya kawasan bekas hutan dan tidak menampakkan lagi bekas tebangan.

e) Lahan terbuka / Daerah tak bervegetasi (LT): Lahan tanpa tutupan vegetasi baik yang bersifat alami maupun artifisial.

Riset juga membandingkan hasil participatory wellbeing asessment (PWA) sebelum dan selama skema ini berjalan untuk mengukur kesejahteraan masyarakat melalui focus group discussion (FGD) dari 30 narasumber. PWA dipilih untuk memberikan kebebasan bagi masyarakat untuk menentukan kriteria kesejahteraan secara mandiri. Data kuantitatif hasil dari FGD tahun 2015 selanjutnya dibandingkan dengan data FGD di tahun 2013 sebelum intervensi dilakukan. Analisis dampak dilakukan secara kualitatif dengan menggunakan wawancara mendalam terhadap 25 narasumber kunci.

\section{HASIL DAN PEMBAHASAN}

\section{Hasil}

\section{Tutupan Hutan}

Hutan Desa Laman Satong dibagi menjadi 2 zona yaitu Zona Lindung dan Zona Pemanfaatan. Zona Lindung seluas 700 ha adalah zona yang disepakati bersama oleh masyarakat sebagai zona yang tidak boleh ada aktivitas penebangan. Zona Pemanfaatan seluas 370 ha adalah zona yang disepakati bersama oleh masyarakat untuk dapat melakukan kegiatan agroforestri.

Hasil analisis citra menunjukkan telah terjadi pembukaan hutan baik di Zona Lindung maupun Zona Pemanfaatan seperti dalam Tabel 1. Perhitungan citra satelit menunjukkan bahwa telah terjadi deforestasi bersih (net deforestation) sebesar -198.33 ha di Zona Lindung dan -105.39 di Zona Pemanfaatan. Nilai deforestasi negatif menunjukkan bahwa terjadi peningkatan tutupan hutan (forest gain) di hutan desa tersebut. Pergerakan dari masing-masing kelas tutupan hutan digambarkan dalam bentuk Matriks Gambar 1 dan Gambar 2, yaitu masing-masing di Zona Lindung dan Zona Pemanfaaatan. 
Tabel 1 Perubahan Tutupan Hutan Sebelum dan Selama Intervensi.

\begin{tabular}{|c|c|c|c|c|}
\hline \multicolumn{2}{|c|}{ Tutupan hutan Laman Satong } & $\begin{array}{l}\text { Luas di Tahun } 2013 \\
\text { (ha) }\end{array}$ & $\begin{array}{l}\text { Luas di Tahun } 2014 \\
\text { (ha) }\end{array}$ & $\begin{array}{c}\text { Perubahan Luas } \\
\text { (ha) }\end{array}$ \\
\hline \multirow{5}{*}{ Zona Lindung } & $\begin{array}{c}\text { Hutan Campuran Rapat } \\
\text { (HCR) }\end{array}$ & 60 & 134 & +74 \\
\hline & $\begin{array}{c}\text { Hutan Campuran Sedang } \\
\text { (HCS) }\end{array}$ & 354 & 359 & +5 \\
\hline & $\begin{array}{c}\text { Hutan Campuran Jarang } \\
\text { (HCJ) }\end{array}$ & 123 & 100 & -23 \\
\hline & Semak Belukar (SB) & 162 & 105 & -57 \\
\hline & Lahan Terbuka (LT) & 1 & 1 & 0 \\
\hline \multicolumn{2}{|r|}{ Sub Total } & 700 & 700 & \\
\hline \multirow{6}{*}{$\begin{array}{c}\text { Zona } \\
\text { Pemanfaatan }\end{array}$} & HCR & 5 & 30.78 & +26 \\
\hline & $\mathrm{HCS}$ & 168 & 187.74 & +20 \\
\hline & HCJ & 62 & 56.61 & -6 \\
\hline & SB & 127 & 80.46 & -47 \\
\hline & LT & 7 & 14.49 & +7 \\
\hline & Tubuh Air & 0 & 0 & 0 \\
\hline \multicolumn{2}{|r|}{ Sub Total } & 370 & 370 & \\
\hline \multicolumn{2}{|r|}{ Total } & 1070 & 1070 & \\
\hline
\end{tabular}

Di Zona Lindung (Tabel 1), luas deforestasi dihitung dari konversi hutan menjadi Semak Belukar (SB) dan Lahan Terbuka (LT). Telah terjadi pembukaan Hutan Campuran Sedang (HCS) sebesar 14.76 ha menjadi SB dan 0.54 ha menjadi LT. Hutan Campuran Jarang (HCJ) juga mengalami konversi sebesar 12.69 ha menjadi SB dan 0.27 ha menjadi LT. Total Deforestasi di Zona Lindung adalah 28.26 ha. Degradasi hutan dihitung dari penurunan tutupan hutan dari Hutan Campuran Rapat (HCR) menjadi Hutan Campuran Sedang (HCS) sebesar 2.16 ha ditambah dengan penurunan HCS menjadi Hutan Campuran Jarang (HCJ) sebesar 14.85 ha. Total degradasi hutan sebesar 17.01 ha.

Peningkatan tutupan hutan dihitung dari peningkatan tutupan Hutan Campuran Sedang (HCS) menjadi Hutan Campuran Rapat (HCR) sebesar 76.23 ha, Hutan Campuran Jarang (HCJ) menjadi Hutan Campuran Sedang (HCS) sebesar 82.53 ha ditambah dengan Semak Belukar (SB) menjadi HCS sebesar 26.73 ha dan menjadi HCJ sebesar 58.14 ha. Total peningkatan tutupan hutan di Zona Lindung sebesar 243.6 ha. Dengan menggunakan perhitungan yang sama dengan di Zona Lindung, di Zona Pemanfaatan pun telah terjadi deforestasi, degradasi, dan peningkatan tutupan hutan (Tabel 3). Deforestasi sebesar 13.2 ha dihitung dari besarnya konversi hutan menjadi Semak Belukar (SB) dan Lahan Terbuka (LT). Konversi tersebut meliputi perubahan tutupan hutan dari Hutan Campuran Rapat (HCR) menjadi SB, Hutan Campuran Sedang (HCS) menjadi SB dan LT, dan Hutan Campuran Jarang (HCJ) menjadi SB dan LT.

Degradasi hutan sebesar 10.7 ha dihitung dari penurunan tutupan hutan. Penurunan tersebut meliputi penurunan HCR menjadi HCS dan HCJ, dan penurunan dari HCS menjadi HCJ. Peningkatan tutupan hutan sebesar 120 ha di Zona Pemanfaatan dihitung dari total peningkatan tutupan hutan yang terjadi di HCS, HCJ, dan SB. Tutupan hutan di HCS meningkat sebesar 26.46 ha menjadi HCR. Tutupan hutan HCJ meningkat menjadi HCR sebesar 0.09 ha dan menjadi HCS sebesar 40.68 ha. Tutupan hutan SB juga mengalami peningkatan menjadi 0.09 ha menjadi HCR, 21.78 ha menjadi HCS, dan 31.05 ha menjadi HCJ. 
Tabel 2 Matriks Pergerakan Kelas Tutupan Hutan di Zona Lindung Hutan Desa.

\begin{tabular}{|c|c|c|c|c|c|c|c|c|}
\hline \multirow{2}{*}{$\begin{array}{c}\text { Perubahan } \\
\text { Area Lindung } \\
\text { darilmenjadi }\end{array}$} & HCR & HCS & $\mathrm{HCJ}$ & SB & LT & Tubuh Air & Total & Perubahan \\
\hline & \multicolumn{7}{|c|}{ Hektar } & \\
\hline HCR & & 2.16 & 0 & 0 & 0 & 0 & 28.26 & Deforestasi \\
\hline HCS & 76.23 & & 14.85 & 14.76 & 0.54 & 0 & 17.01 & Degradasi Hutan \\
\hline $\mathrm{HCJ}$ & 0 & 82.53 & & 12.69 & 0.27 & 0 & 243.6 & Peningkatan Tutupan Hutan \\
\hline SB & 0 & 26.73 & 58.14 & & 0.63 & 0 & & \\
\hline LT & 0 & 0 & 0 & 0.99 & & 0 & & \\
\hline Tubuh Air & 0 & 0 & 0 & 0 & 0 & & & \\
\hline
\end{tabular}

Tabel 3 Matriks Pergerakan Kelas Tutupan Hutan di Zona Pemanfaatan Hutan Desa.

\begin{tabular}{|c|c|c|c|c|c|c|c|c|}
\hline \multirow{2}{*}{$\begin{array}{c}\text { Perubahan } \\
\text { Zona } \\
\text { Pemanfaatan } \\
\text { darilmenjadi }\end{array}$} & HCR & $\mathrm{HCS}$ & HCJ & SB & LT & Tubuh Air & Total & Perubahan \\
\hline & \multicolumn{7}{|c|}{ Hektar } & \\
\hline HCR & & 0.9 & 0.09 & 0.09 & 0 & 0 & 13.2 & Deforestasi \\
\hline $\mathrm{HCS}$ & 26.46 & & 9.72 & 4.05 & 3.42 & 0 & 10.7 & Degradasi Hutan \\
\hline HCJ & 0.09 & 40.68 & & 5.04 & 0.63 & 0 & 120 & Peningkatan Tutupan Hutan \\
\hline SB & 0.09 & 21.78 & 31.05 & & 4.14 & 0 & & \\
\hline LT & 0 & 0 & 0 & 0.99 & & 0 & & \\
\hline Tubuh Air & 0 & 0 & 0 & 0 & 0 & & & \\
\hline
\end{tabular}

\section{Kesejahteraan Masyarakat}

Penentuan kriteria kesejahteraan ditentukan oleh peserta pertemuan dalam bentuk focus group discussion (FGD) di tingkat RT dengan melihat kondisi riil di lingkungan rumah tangga. Kesejahteraan masyarakat dibagi ke dalam 3 kelompok yaitu kelompok miskin, kelompok sedang dan kelompok kaya. Ada 8 indikator yang teridentifikasi di antaranya: (1) Perumahan, (2) Listrik, (3). Elektronik dan transportasi, (4) Kepemilikan tanah, (5) Kebun, (6) Pekerjaan, (7) Penghasilan, (8) Fasilitas MCK. Kriteria masing-masing indikator ditunjukkan dalam Tabel 4.

Tabel 4 Indikator Tingkat Kesejahteraan yang dibuat berdasarkan Participatory Wellbeing

\begin{tabular}{|c|l|l|l|}
\hline Indikator & \multicolumn{1}{c|}{ Miskin } & \multicolumn{1}{c|}{ Sedang } & \multicolumn{1}{c|}{ Kaya } \\
\hline \multirow{5}{*}{ Perumahan } & Dinding bambu atau & Atap seng atau Genteng, & Atap seng, dinding semen, lantai \\
& papan, atap daun, lantai & dinding papan, lantai & porselen. Bangunan 6x12 $\mathrm{m}^{2}$. \\
& papan, rata-rata & Papan. Bangunan 6x9 & Punya ruang Dapur, ruang tamu, \\
& bangunan 4x6 $\mathrm{m}^{2}$. & $\mathrm{m}^{2}$. Terdiri dari dapur, \\
& Terdiri dari dapur, & ruang tamu, kamar tidur & ruang makan, kamar tidur 3-4 \\
& buah. Berlantai 1 atau 2. \\
& ruang tamu, kamar tidur. & 2-3 buah. & \\
\hline
\end{tabular}




\begin{tabular}{|c|c|c|c|}
\hline Indikator & Miskin & Sedang & Kaya \\
\hline Listrik & $\begin{array}{l}\text { Menyambung listrik dari } \\
\text { tetangga, menggunakan } \\
\text { pelita ketika mati lampu }\end{array}$ & $\begin{array}{l}\text { Memiliki sambungan } \\
\text { listrik sendiri } 450 \mathrm{kWh} \text {, } \\
\text { dan menggunakan lilin } \\
\text { ketika mati lampu }\end{array}$ & $\begin{array}{l}\text { Memiliki sambungan listrik } \\
\text { sendiri } 900 \mathrm{kWh} \text {, memberikan } \\
\text { tumpangan listrik kepada } \\
\text { tetangga, dan memiliki Genset } \\
\text { sendiri yang digunakan ketika } \\
\text { mati lampu }\end{array}$ \\
\hline $\begin{array}{l}\text { Elektronik \& } \\
\text { Transportasi }\end{array}$ & Radio, sepeda & TV, Sepeda Motor & $\begin{array}{l}\text { Kulkas, TV, Sepeda, Sepeda } \\
\text { Motor, Mobil }\end{array}$ \\
\hline $\begin{array}{l}\text { Kepemilikan } \\
\text { Tanah }\end{array}$ & Maksimal 5 ha/ keluarga & 5-10 ha/keluarga & Lebih dari 10 ha/keluarga \\
\hline Kebun & $\begin{array}{l}\text { Maksimal } 2 \text { ha berupa } \\
\text { kebun buah dan kebun } \\
\text { karet }\end{array}$ & $\begin{array}{l}2-7 \text { ha berupa kebun } \\
\text { buah dan kebun karet }\end{array}$ & $\begin{array}{l}7 \text { ha lebih berupa kebun buah, } \\
\text { kebun karet, dan gaharu }\end{array}$ \\
\hline Pekerjaan & $\begin{array}{l}\text { Buruh kasar, petani, } \\
\text { harian lepas, menoreh } \\
\text { karet, berburu }\end{array}$ & $\begin{array}{l}\text { Karyawan harian tetap, } \\
\text { guru/PNS, buruh sawit }\end{array}$ & $\begin{array}{l}\text { Karyawan harian Tetap, } \\
\text { pengusaha }\end{array}$ \\
\hline Penghasilan & $\begin{array}{l}\text { Kurang dari } 1.2 \\
\text { juta/bulan }\end{array}$ & $1.2-5$ juta/bulan & Lebih dari 5 juta /bulan \\
\hline Fasilitas MCK & $\begin{array}{l}\text { Tidak punya } \mathrm{WC} \text { di } \\
\text { dalam rumah }\end{array}$ & $\begin{array}{l}\text { WC di dalam rumah; } \\
\text { Dinding berupa papan }\end{array}$ & WC dan Lantai dari porselen \\
\hline
\end{tabular}

Hasil penilaian PWA di tahun 2015 selanjutnya dibandingkan dengan PWA di tahun 2013. Hasil perbandingan ditampilkan dalam Gambar 1. Gambar 1 menggambarkan adanya peralihan kelompok miskin menuju kelompok sedang hampir di semua RT. Untuk melihat lebih dalam perubahan pada kelompok miskin, peneliti menganalisis perubahan tersebut dalam Tabel 5.

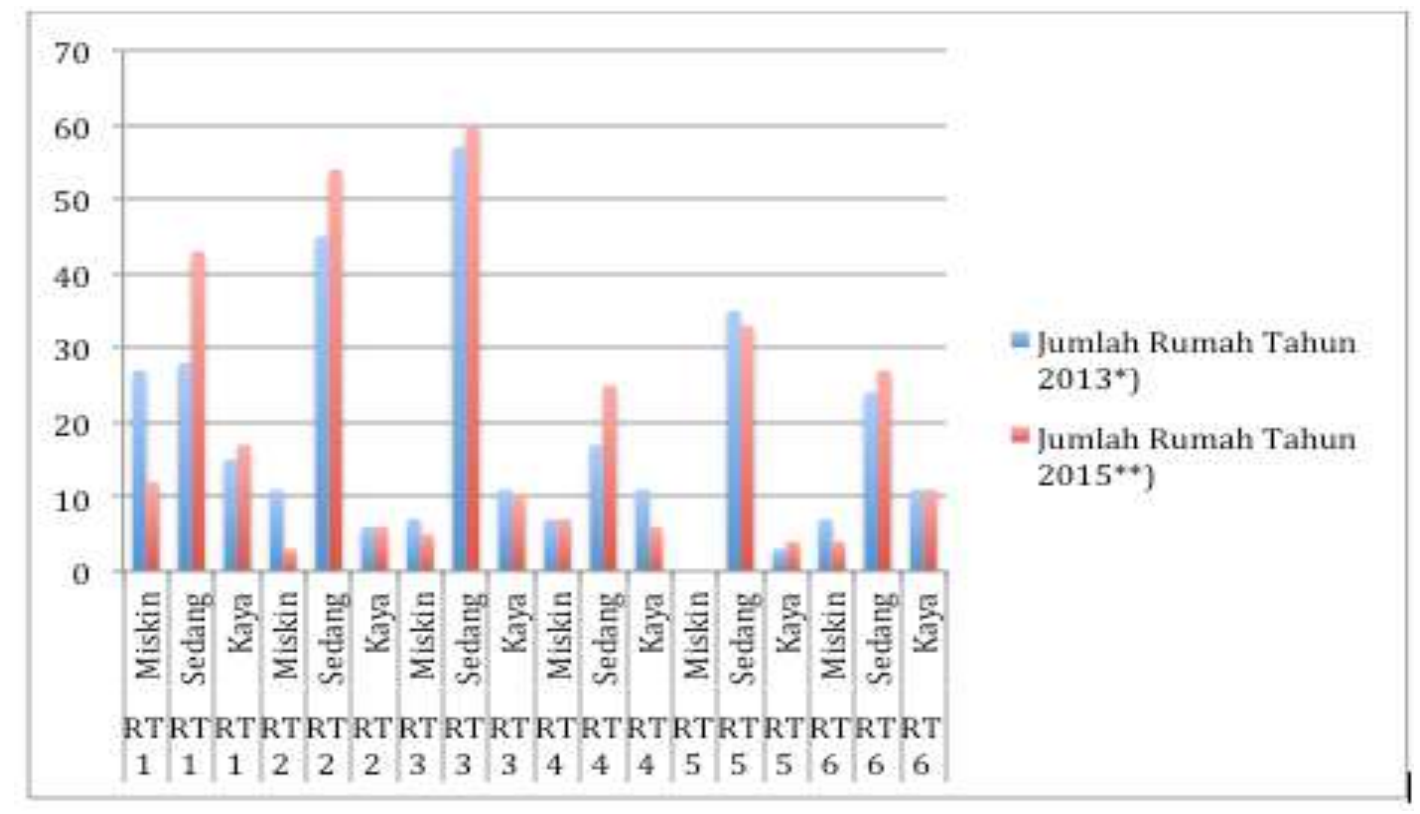

*) Sumber: Hutabarat \& Rachmansah (2013) telah diolah kembali

**) Hasil PWA oleh peneliti di tahun 2015

Gambar 1 Pergerakan Perubahan Kelompok Miskin, Sedang, dan Kaya di tiap RT 
Perhitungan dalam tabel 3 menunjukkan bahwa telah terjadi peningkatan kesejahteraan dari kelompok miskin sebesar $47.46 \%$. Namun demikian berdasarkan hasil wawancara mendalam terhadap tokoh masyarakat, tokoh pemuda, dan penerima manfaat yang diuji validitasnya dengan menggunakan teknik triangulasi, perubahan kelompok miskin menuju kelompok sedang disebabkan oleh intervensi lain yang berjalan paralel dengan inisiasi skema REDD+ dan PJL, yaitu program bedah rumah.

Tabel 5 Perubahan Jumlah Masyarakat Miskin

\begin{tabular}{|l|c|c|c|c|}
\hline $\begin{array}{l}\text { Lokasi } \\
\text { RT })\end{array}$ & $\begin{array}{l}\text { Tahun 2013 } \\
\text { (jumlah keluarga)*) }^{*}\end{array}$ & Tahun 2015 (jumlah keluarga)**) & Selisih & Persentase Pengurangan (\%) \\
\hline RT 1 & 27 & 12 & 15 & 55.56 \\
\hline RT 2 & 11 & 3 & 8 & 72.73 \\
\hline RT 3 & 7 & 5 & 2 & 28.57 \\
\hline RT 4 & 7 & 7 & 0 & - \\
\hline RT 5 & 0 & 0 & 0 & - \\
\hline RT 6 & 7 & 4 & 3 & 42.86 \\
\hline Total & 59 & 31 & 28 & 47.46 \\
\hline
\end{tabular}

*) Sumber: Hutabarat \& Rachmansah (2013) telah diolah kembali

**) Hasil PWA oleh peneliti di tahun 2015

\section{Pembahasan}

\section{Tutupan Hutan}

Meskipun terdapat deforestasi dan degradasi di Hutan Desa Laman Satong, namun variabel tutupan hutan mengalami peningkatan (forest gain) sebagai dampak intervensi inisiasi skema REDD+ dan PJL diterapkan di hutan desa. Hasil riset melalui wawancara mendalam dan observasi di lapangan menunjukkan bahwa intervensi inisiasi skema REDD+PJL berdampak mengurangi deforestasi secara langsung melalui penggunaan dana untuk patroli dan rehabilitasi lahan. Hasil penelitian ini sejalan dengan penelitian inisiasi skema REDD+PJL yang dilakukan oleh Bond et al. (2009) dan Wunder (2009) yang menilai bahwa inisiasi skema PJL untuk REDD+ memiliki peran yang penting untuk mengurangi alih fungsi dan kerusakan hutan. Kemampuan masyarakat dalam mengelola hutan tersebut menunjukkan bahwa secara kelembagaan, Lembaga Pengelola Hutan Desa (LPHD) telah mampu menjalankan fungsi pengelolaan sumberdaya manusia untuk kegiatan konservasi secara mandiri.

Meskipun nilai pembayaran yang diterima oleh masyarakat relatif kecil dibandingkan dengan kesempatan yang hilang (opportunity cost) apabila hutan dibuka, masyarakat masih bersedia menerima pembayaran tersebut untuk berbagai kegiatan yang disepakati bersama. Keberterimaan masyarakat terhadap nilai pembayaran yang kecil berbeda dengan penelitian yang dilakuakn oleh van Noordwijk dan Leimona, (2010) yang menyatakan bahwa pembayaran jasa lingkungan sangat ditentukan oleh besarnya uang pengganti yang hilang. Berdasarkan perhitungan nilai kontrak yang disepakati antara pembeli jasa lingkungan dan masyarakat, pemilik lahan akan mendapatkan kurang lebih Rp. 330 ribu per 2 tahun terakhir. Angka tersebut sangat kecil dibandingkan dengan perladangan yang biasa mereka lakukan. Jika berladang padi mereka dapat menghasilkan Rp. 400 ribu/bulan (Afiff et al. 2011).

Keberterimaan masyarakat terhadap skema inisiasi ini tidak didorong oleh perhitungan kesempatan yang hilang, namun didorong oleh faktor persamaan kepentingan untuk melindungi sumber air sebagai jasa lingkungan. Sebanyak 100\% narasumber menyatakan bahwa mereka akan tetap menjaga hutannya karena alasan sumber air ini.

Faktor lain yang mendorong keberterimaan masyarakat adalah karena masyarakat tidak lagi sepenuhnya mengandalkan perladangan, namun seperti diidentifikasi oleh Afiff et al. (2012), mata pencaharian masyarakat 
mulai berpindah dari berladang ke mata pencaharian lain seperti menjadi karyawan perusahaan sawit dan bertani menetap. Masyarakat menjadikan lahan berladang mereka sebagai kebun buah-buahan yang dapat dipanen sebagai penghasilan tambahan.

Selain dampak positif, skema ini juga memunculkan potensi ancaman keberlanjutan berupa konflik internal. Konflik muncul dari ketidakpuasan pemilik lahan yang menguasai dan mengelola agroforestri di zona pemanfaatan seluas 39\% dari total hutan desa. Ketidakpuasan pemilik lahan adalah tentang bagaimana seharusnya uang yang diterima oleh LPHD dimanfaatkan oleh para pemilik lahan. Sebesar 56\% narasumber menilai bahwa dana belum dikelola secara transparan terutama terkait dengan pemanfaatan uang untuk pemilik lahan agar dapat dibagi secara individual. Keinginan para pemilik lahan untuk mendapatkan pembagian secara individu imbalan tersebut mendukung studi PJL di tapak yang lain yang dilakukan oleh Kaczan et al. (2013) yang menyatakan bahwa keberhasilan pengurangan deforestasi disebabkan mekanisme pemberian imbalan PJL dalam bentuk tunai dan non tunai lebih menarik bagi pemilik lahan secara individual dibandingkan dalam bentuk pembayaran tunai dalam group. Jika pola individual ini terus berlanjut maka keberlanjutan skema ini sangat ditentukan oleh individu bukan lagi oleh komunal.

\section{Kesejahteraan Masyarakat}

Ditinjau dari aspek ekonomi, hasil riset menunjukkan bahwa penggunaan dana skema ini belum memberikan dampak kesejahteraan terhadap masyarakat. Waktu pengukuran yang singkat yaitu 2 tahun sejak dimulainya inisiasi skema REDD+ dan PJL menjadi sebab mengapa dampak terhadap kesejahteraan belum dapat terukur. Selain itu terbatasnya nilai uang yang diterima oleh masyarakat menjadi alasan penundaan kegiatan pemberdayaan masyarakat.

Nilai kontrak yang ada saat ini belum dapat dimanfaatkan secara optimal oleh masyarakat untuk kegiatan pengembangan ekonomi masyarakat. Dari total 150 juta rupiah uang yang diterima oleh masyarakat di tahun ke-2, masyarakat menyepakati 23\% dari total yaitu sebesar Rp. 34500000 untuk kegiatan pengembangan ekonomi. Nilai tersebut dirasakan oleh masyarakat sangat kecil untuk memulai usaha ekonomi sehingga mereka menabung terlebih dahulu alokasi pembiayaan tersebut untuk dimanfaatkan ketika sudah dirasa cukup.

Peluang masyarakat untuk mendapatkan dana yang lebih besar dari skema REDD+ dan PJL sangat tergantung dengan ketersediaan dana baik melalui pendanaan hibah maupun pasar karbon sukarela. Dengan perhitungan ketersediaan total $4258 \mathrm{tCO}_{2} \mathrm{e}$ dapat terjual sepenuhnya dengan harga per ton USD 14, maka potensi penerimaan adalah sebesar USD 59612 00. Dengan kurs Rp. 13,000, maka potensi dana yang dapat digunakan setiap tahunnya adalah sebesar Rp. 774996000.

Meskipun dampak positif yang diukur dari tingkat kesejahteraan belum dapat terukur, skema tersebut telah memberikan dampak positif secara sosial berupa pemberdayaan kelompok ibu-ibu, tersedianya bantuan untuk kelompok miskin, ketersediaan sumber air bersih, peningkatan pengetahuan masyarakat, tersedianya lapangan pekerjaan sebagai tenaga kerja patroli, terbantunya masyarakat dari kebakaran karena adanya patroli, dan memberikan kebanggaan bagi masyarakat karena telah menjadi contoh keberhasilan pengelolaan hutan berkelanjutan. Dampak positif tersebut menunjukkan bahwa masyarakat mampu mengelola dana inisiasi skema PJL melalui mekanisme pembagian manfaat (benefit sharing) untuk kegiatan sosial. Meskipun dampak positif telah dirasakan secara sosial, skema ini juga menimbulkan dampak negatif yaitu potensi konflik sosial yang berawal dari kecurigaan pengelolaan keuangan.

\section{SIMPULAN}

Variabel tutupan hutan mengalami peningkatan (forest gain) selama intervensi inisiasi skema REDD+ dan PJL diterapkan di hutan desa. Inisiasi skema tersebut memberikan pendanaan yang memadai untuk kegiatan pengamanan area hutan dan rehabilitasi area melalui penanaman pohon buah-buahan. Namun demikian persoalan belum disepakatinya mekanisme pembagian imbalan uang untuk pemilik lahan menjadi 
ancaman terhadap tutupan hutan karena para pemilik lahan merasa tidak mendapatkan pengganti kesempatan yang hilang (opportunity cost) dari tidak diperbolehkannya membuka lahan.

Variabel kesejahteraan masyarakat belum dapat diukur dari intervensi inisiasi skema REDD+ dan PJL. Faktor penting mengapa variabel ini belum bisa diukur adalah waktu pengukuran yang singkat yaitu 2 tahun dari inisiasi skema ini mulai diterapkan dan nilai uang yang tidak memadai menurut masyarakat untuk memulai kegiatan pemberdayaan ekonomi.

\section{DAFTAR PUSTAKA}

[BPS] Badan Pusat Statistik Kabupaten Ketapang. 2014. Kecamatan Matan Hilir Utara dalam angka 2014. Ketapang : BPS.

[BSN] Badan Standardisasi Nasional. 2010. SNI 7645:2010 tentang Klasifikasi penutup lahan. Badan Standardisasi Nasional. Jakarta : Badan Standardisasi Nasional.

[FFI] Fauna \& Flora International. 2012. Plan Vivo Project Idea Note (PIN): Community Forest Ecosystem Services, Indonesia. Jakarta : Fauna \& Flora International.

[FFI] Fauna \& Flora International. 2015. Plan Vivo annual report 2015: Laman Satong Village Forest Carbon Project. Jakarta : Fauna \& Flora International

Afiff S, Purwanto SA, Utami S, Haryono, Nugroho AC, Rokhdian AD. 2011. Kajian sosial dan kelembagaan terkait dengan pengelolaan hutan dalam Skema REDD di Kabupaten Ketapang, Provinsi Kalimantan Barat. Jakarta : Pusat Kajian Antropologi, FISIP, Universitas Indonesia.

Bond I, Grieg-Gran M, Wertz-Kanounnikoff S, Hazlewood P, Wunder S, Angelson A. 2009. Incentives to sustain forest ecosystem services: a review and lessons for REDD. London (UK), Bogor. Washington : International Institute for Environment and Development, London, UK with CIFOR, Bogor, Indonesia, and World Resources Institute, Washington D.C., USA.

Departemen Kehutanan dan Badan Pusat Statistik. 2007. Identifikasi Desa dalam Kawasan Hutan. 2007. Jakarta : Departemen Kehutanan dan Badan Pusat Statistik.

Hutabarat J, Rachmansah A. 2013. Community forest ecosystem service V.1.3. (intervention: avoided deforestation and forest conservation on mineral soil). Plan Vivo Technical Specification. Jakarta : Fauna \& Flora International.

Kaczan D, Swallow M, Adamowicz V. 2013. Designing a payments for ecosystem services (PES) program to reduce deforestation in Tanzania: An assessment of payment approaches. Ecol Econ. 95: 20-30.

Lapeyrea R, Pirardb R, Leimona B. 2015. Payments for environmental services in Indonesia: What if economic signals were lost in translation? Land Use Policy. 46: 283-291.

Leimona B, Joshi L. 2009. Can rewards for environmental services benefit the poor? Lessons from Asia. Int J Commons. 3: 82-107.

Pemerintah Indonesia. 2009. Undang-Undang No. 32 tahun 2009 tentang Perlindungan dan Pengelolaan Lingkungan Hidup. Jakarta: Sekretariat Negara.

Pemerintah Indonesia. 2014. Peraturan Menteri Kehutanan Republik Indonesia Nomor: P.89/Menhut-II/2014 Tentang Hutan Desa. Jakarta: Kementerian Kehutanan.

Rositah E. 2006. Governance Brief: Kemiskinan Masyarakat Desa sekitar Hutan dan Penanggulangannya. Bogor : CIFOR.

Tacconi L, Mahanty S, Suich H. 2013. The Livelihood Impacts of Payments for Environmental Services and Implications for REDD+. Soc Natur Resour. 26 (6): 733-744.

Tacconi L. 2012. Redefining Payments for Environmental Services. Ecol Econ. 73: 29-36.

Torpey-Saboe N, Andersson K, Mwangi E, Persha L, Salk CW. 2015. Benefit Sharing Among Local Resource Users: The Role of Property Rights. World Dev. 72: 408-418. 
Wunder S. 2009. Can payments for environmental services reduce deforestation and forest degradation? Di dalam A. w.-K. Angelsen. 2009. Realising REDD+: National strategy and policy options (hlm 213-224). Bogor : CIFOR.

Yayasan Resource Development Center. 2009. Peluang Pemanfaatan Potensi Karbon Hutan Dalam Isu Perubahan Iklim. Jakarta: Forest Governance and Multistakeholder Forestry Programme (MFP) II. 